\title{
The Relationship between Boredom, Interpersonal Closeness / Bullying and Victimization in the School Environment
}

\author{
Vassou Vasileia ${ }^{1}$, Vassiou Aikaterini², Stavropoulos Vasileios ${ }^{2}$ and Chaintouti Vasiliki ${ }^{3}$ \\ ${ }^{1}$ University of Twente, Netherlands \\ ${ }^{2}$ University of Thessaly, Greece \\ ${ }^{3}$ Special Educator, Lamia, Greece
}

Submission: August 22, 2017; Published: September 06, 2017

*Corresponding author: Vasileia Vassou, Faculty of Behavioral Sciences, University of Twente, Calslaan 1-102, 7522 MH Enschede, The Netherlands; Tel: +310-645417596, Email: v.vassou@student.utwente.nl

\begin{abstract}
Bullying has significant long-term effects even in adult life Rigby, Johnson [1-2]. Research has demonstrated a strong association between boredom and various measures of aggression including physical and verbal aggression, anger, and hostility Fahlman et al. [3], Rupp, Vodanovich [4], while taking the perspective of another person often leads to more compassionate perceptions and pro-social behaviour toward that person (Myers \& Hodges, 2011).In this study, we examined whether boredom and interpersonal closeness predict bullying and victimization. Participant's were 247 Greek students (43.3\% and 56.7\% girls) of Senior High School. The students filled in three scales: Bullying/Victimization Scale Olweus [5], Boredom-Disengagement Scale Fahlman et al. [3] and Inclusion of Others in Self scale Aron et al. [6] Result syndicated that boredom was positively correlated to bullying. Moreover, boys got involved in bullying incidents more than girls.
\end{abstract}

Keywords: Bullying; Victimization; Boredom; Interpersonal closeness

\section{Introduction}

Bullying at school is a type of violent and aggressive behaviour among students, which occurs in many countries around the world and, in recent years, keeps increasing and causing problems for students, their families and the school itself Rigby [1] . Also, school bullying has significant long-term effects even in adult life Rigby, Johnson [2]. Based on the premises that research has demonstrated a strong association between boredom proneness and various measures of aggression including physical and verbal aggression, anger, and hostility Fahlman et al. [3], Rupp [4], while taking the perspective of another person often leads to more compassionate perceptions and pro-social behaviour toward that person Myers [4], we examined whether boredom and interpersonal closeness predict bullying and victimization. Understanding the potentially complex relations among boredom and interpersonal closeness can have implications for the assessment and prevention of bullying and victimization at school.

\section{Bullying}

The study of school bullying was commenced in Scandinavia in the 1970 s by Olweus [7], who was trying to define the phenomenon. In more recent studies, bullying is defined as an aggressive behaviour in which an individual harms another person within the context of a power imbalance Volk et al. [8]. Children who are involved in bullying may act as perpetrators, passive victims and aggressive victims or bully victims. That is, they act as bullies or victims in different occasions Austin [9], Bowers et al. [10], Wolke et al. [11].

There are several factors implicated in bullying. For example, bullies are more likely to participate in other forms of antisocial behaviour, get along with more antisocial peers and show greater antisocial behaviours and lower social competence skills Bollmer et al. [12], Cunningham [13], Jolliffe et al.[14], Mouttapa et al. [15], Unnever [16]. Victims of bullies, on the other hand, 
consistently experience lower quality in friendship relations and report higher levels of internalizing problems, such as anxiety and depression, and lower self-esteem and social competence than other children Bollmer et al. [12], Haynie et al. [17], Juvonen et al. [18], Marini et al. [19], Unnever [16] (Table 1).

Table 1: Correlations between variables of study.

\begin{tabular}{|c|c|c|c|c|}
\hline & BUL & VIC & BOR & IOS \\
\hline BUL & $.47^{*}$ & $.21^{* *}$ & -.09 & -.02 \\
\hline VIC & & $.24^{* *}$ & $-.15^{*}$ & -.09 \\
\hline BOR & & & & -.00 \\
\hline IOS & & & & \\
\hline
\end{tabular}

Note: $B U L=B$ ullying, $V I C=$ Victimization, $B O R=$ Boredom, $I O S=0$ ther In Self Scale.

${ }^{* *}$ correlation is significant at the 0.01 level (2-tailed)

\section{Boredom and Bullying}

Boredom is a ubiquitous human experience characterised by a failure to engage with one's environment - a failure that is negatively valenced Eastwood et al. [20]. Higher levels of boredom proneness can negatively impact attention capacities, emotional well-being, and have been associated with problematic behavioural consequences. For instance, high boredom-prone individuals are more likely to engage in addictive behaviours such as substance abuse and problem gambling e.g. Mercer, Eastwood [21], impulsive and higher risk-taking behaviours Joireman et al. [22], Kass, Vodanovich [23], and tend to have poorer outcomes associated with achievement settings Pekrun et al. [24]. Boredom proneness has also been related to inappropriate expression of anger, and deficits in controlling aggressive feelings Dahlen et al. [25]. When controlling for sensation seeking and impulsivity, research has demonstrated a strong association between boredom proneness and various measures of aggression including physical and verbal aggression, anger, and hostility Fahlman Mercer-Lynn et al. [3], Rupp, Vodanovich [4].

Students frequently feel bored at school. According to Larson, Richards [26], students felt bored $32 \%$ of the time they spent in class. Students feel less bored in classes with low levels of perceived monotony, a factor that can be influenced by teachers teaching methods. Another factor that impacts the levels of student boredom is the perceived value of lessons. Highly useful or valuable courses and also ones that allow students to have partial control over their learning outcomes decrease experiences of boredom Daschmann et al. [27]. Students who experience high levels of boredom at school are at higher risk of negative academic outcomes, such as low grades, school absenteeism, and drop-out rates Robinson [28]; Wasson [29], drug consumption Johnston, O'Malley [30], Orcutt [31], Samuels, Samuels [32], eating disorders Abramson, Stinson [33], Leon, Chamberlain [34], hostility Broadbent, Gath [35], depression Giambra, Traynor [36], and juvenile delinquency Harris [37], Vodanovich, Kass [38].

In this study, we focused on students' disengagement as a component of boredom, because most definitions of boredom ( $n=29 ; 66 \%$ ) suggest that boredom involves feeling withdrawn from one's environment (e.g., Greenson [39], Fahlman et al. [3], Mercer, Eastwood [21] and many researchers view this as the defining feature of boredom e.g., Fahlman [40], Goldberg et al. [41], Passik [42]. Students who experience high levels of disengagement have been found to be at higher risk of persistent educational problems such as low achievement, high dropout rates, and high rates of student alienation Chapman et al. [43], Fredricks [44] (Table 2).

Table 2: Descriptive of the variables of the study.

\begin{tabular}{|c|c|c|c|}
\hline M(SD) & N & Missing & \\
\hline BUL & $16.28(6.08)$ & 237 & 10 \\
\hline VIC & $16.40(6.50)$ & 237 & 4 \\
\hline BOR & $38.48(12.20)$ & 238 & 9 \\
\hline IOS & $5.15(1.26)$ & 247 & 0 \\
\hline
\end{tabular}

Note: BUL=Bullying, VIC=Victimization, BOR=Boredom, IOS=Other In Self Scale.

\section{Interpersonal Closeness and Bullying}

Interpersonal relationships seem to influence students' involvement in bullying and victimization incidents. Bullies and bully-victims seemed to score higher in emotionality and physical activity scales and lowers in popularity scales Pellegrini et al. [45]. In particular, bully-victims reported that they had fewer good friends than bullies did Unnever [16], while bullies were less isolated than victims, but more isolated than the not involved students. Especially, having friends and been liked by your peers proved to be protective factors against victimization, the latter more so than the former Pellegrini et al. [45]. Children's interpersonal behaviours influence their relationships with other students at school. Reunamo et al. [46] stated that bullying seems to be an effective way to get in contact with other children.

Table 3: Multiple regression analysis tables: Dependent variable: Bullying.

\begin{tabular}{|c|c|c|c|c|c|c|}
\hline & & $\begin{array}{l}\text { Unstandarlised } \\
\text { coefficients }\end{array}$ & $\begin{array}{c}\text { Standardised } \\
\text { Coefficients }\end{array}$ & & & \\
\hline & B & Std.Error & Beta & $\mathbf{t}$ & $\mathbf{p}$ & $\mathbf{r}$ \\
\hline (Constant) & 14.81 & 2014 & & 6.91 & .000 & \\
\hline Boredom & .10 & .03 & .21 & 3.31 & .001 & $.21^{* *}$ \\
\hline
\end{tabular}

${ }^{* *}$ correlation is significant at the 0.01 level (2-tailed) 
The child that bullies others is able to attract other children's attention and make them process the situation on his or her own terms. Thus, bullying is an effective strategy for getting into contact with others and the child that bullies is able to determine the content of the interaction. There are also findings that demonstrate the negative relationships between children's experiences of victimization and their close peer relationships at school Leadbeater et al. [47]. Greek studies also resulted in a significant differentiation of bully/victims from the rest of the groups, especially in terms of their low social acceptance, high Machiavellism and negative self-esteem Andreou [48-51], Andreou et al. [51] as well as their low problem-solving abilities Andreou [49]. This group also appeared to show more symptoms of disruptive behaviour and conduct disorders than the rest Kokkinos, Panayiotou [52]. In addition, bully-victims constituted a distinct group in terms of their highly positive attitudes toward bullying Andreou et al. [51] and lack of positive interactions with peers Psalti [53] (Table 3).

In our study, we included self-other inclusion, as an aspect of interpersonal closeness and a sense of belonging. Recent research has demonstrated that students with high sense of belonging do not want to escape from their peers or to oppose them Reunamo et al. [46], Johnson [54], Nipedal et al. [55], whereas students who feel separated from other people around them are expected to be involved in more victimization occasions than students who have strong relations with others Leadbeater et al. [47].

\section{Individual Differences Factors and Bullying}

School bullying is often associated with age and individual differences factors, such as age and gender. Specifically, both bullying and victimization tend to be reduced as students move from elementary to high school although bullying increases initially in the transition from primary to high school and then reduced Pellegrini, Long [56]. There is evidence that age is associated with intimidation rather than aggression Farrington [57], Loeber, Stouthamer-Loeber [58]. In fact, bullying tends to increase and reach a peak during early adolescence along with a drop of grades in high school Nansel et al. [59]; Pellegrini, Bartini [60]. Swettenham et al. [61-63] reported that victimization occurs during early childhood (ages 4-6) and it seems to be a frequent experience for many children. The main difference between the victimization experienced at early childhood and at a later stage is that the former tends to be short-lived, unlike the endurance of victimization in middle childhood and adolescence e.g., Boulton, Monks Smith [61], Salmivalli et al. [64] (Table 4).

Table 4: Multiple regression analysis Tables: Dependent variable: Bullying.

\begin{tabular}{|c|c|c|c|c|c|c|}
\hline & & $\begin{array}{l}\text { Unstandarlised } \\
\text { coefficients }\end{array}$ & $\begin{array}{c}\text { Standardised } \\
\text { Coefficients }\end{array}$ & & & \\
\hline & B & Std.Error & Beta & t & $\mathbf{p}$ & $\mathbf{r}$ \\
\hline (Constant) & 19.56 & 3.18 & 6.14 & .000 & & \\
\hline IOS & -.41 & .31 & .08 & -1.31 & .190 & -.09 \\
\hline Gender & -3.46 & .80 & -.28 & -4.31 & & \\
\hline
\end{tabular}

Note: IOS=Other in Self Scale

${ }^{* *}$ correlation is significant at the 0.01 level (2-tailed)

As regards gender, bullying and victimization incidents are more common among boys than girls Stassen, Berger [65]. Generally speaking, men are more often bullies than women, and men are intimidated mostly by men. Women are intimidated both by men and women Eder et al. [66]; Farrington [67]; Thorne [68]. Furthermore, the number of women who intimidate steadily decreases as they become older, whereas the prevalence of male bullies remains almost the same from eight to sixteen years of age Farrington, [67].

\section{The Present Study and the Hypotheses}

The purpose of the present study was to examine factors which predict bullying and victimization. We focused to boredom and interpersonal closeness because, as mentioned above, they have associations with students' behaviours. First, we examined relationships between boredom and students' involvement in bullying and victimization. Based on previous research that has shown a relationship between students' disengagement and problematic behaviours at school Chapman et al. [43], Fredricks [44], we expected that students who feel more boredom will involve more in bullying (Hypotheses 1).

Moreover, as prior research has shown that bullying is an effective strategy for getting into contact with others Reunamo et al. [46], Johnson [54], and that victimization has a negative relationship with peer relationships at school(Nipedal et al. [55]; Leadbeater et al. [47], we expected that students who are less connected to other people around them will involve more in bullying (Hypothesis 2a), whereas students who are more connected to other people around them will involve less in victimization incidents (Hypothesis $2 \mathrm{~b}$ ). We further examined the extent to which there are gender differences in bullying/ victimization. Following the same line of reasoning that females typically engage in less direct or overt aggression than do males e.g., Crick 1995, Tisak 1996, we expected that girls will involve less in bullying and more in victimization Hypotheses $3 \mathrm{a}$ and $3 \mathrm{~b}$ (Table 5). 
Table 5: Multiple regression analysis tables: Dependent variable: Victimization.

\begin{tabular}{|c|c|c|c|c|c|c|}
\hline & & $\begin{array}{l}\text { Unstandarlised } \\
\text { Coefficients }\end{array}$ & $\begin{array}{c}\text { Standardized } \\
\text { coefficients }\end{array}$ & & & \\
\hline & B & Std. Error & Beta & $\mathbf{t}$ & p & $\mathbf{r}$ \\
\hline (constant) & 27.64 & 3.35 & 8.23 & .000 & & \\
\hline IOS & -.76 & .33 & -.15 & -2.26 & .25 & $-.15^{*}$ \\
\hline Gender & -.04 & .85 & -.00 & -.05 & .958 & \\
\hline
\end{tabular}

Note: $I O S=O t h e r$ in Self Scale.

${ }^{*}$ correlation is significant at the 0.05 level (2-tailed)

\section{Method}

\section{Participants}

The sample comprised 250 Greek students attending Senior High School $(M=16.35, \mathrm{SD}=1.09)$. There were $43.3 \%$ and $56.7 \%$ girls.

\section{Instruments}

Three different scales were used to measure boredom, interpersonal closeness, and bullying/victimization. All scales were translated from English to Greek in order to be possible for the students to fill in the questionnaires without any difficulty. More specifically, researchers initially translated the three scales, the Boredom-Disengagement Scale, the other in Self Scale and the Bullying/Victimization Scale, from English into Greek. Then a back translation to English was made so as assure the accuracy of the meaning of the translated items. A number of mistakes identified were corrected.

\section{Boredom-Disengagement Scale}

The Boredom-Disengagement scale comes from the Multidimensional State Boredom Scale Fahlman et al. [3] that assesses five dimensions of boredom: Disengagement, High Arousal, Low Arousal, Inattention, and Time Perception. From the five-factor structure of the initial scale only the first subscale was used. Disengagement subscale has 10 items include statements such as 'I wish I was doing something more exciting'. Students responded to each item on a seven-point Like rt-type scale, from 1 = totally disagree to 7 = totally agree. Cronbach's alpha reliability was .83 .

\section{Inclusion of Others in Self scale}

The Inclusion of Others in Self scale (IOS) Aron et al. [6] has only one item and it consists of seven pairs of circles -one circle representing the self and the other representing another person-that vary in the extent to which they overlap with each other. The scale was initially designed as a measure of self-other inclusion and relationship closeness. In other words, this scale measures the interpersonal closeness, how people feel their self is related to other people. What is more, the IOS Scale was used so as to interpret people's sense of being interconnected with other people around them. Participants were instructed to indicate which pair of circles (the range of response was from 1 to 7) best described their relationship with others. Higher scores corresponded to pairs of circles that increasingly overlapped, and thus represented greater self-other overlap.

\section{Revised Bullying and Victimisation Questionnaire (BVQ-R)}

The BVQ-R scale consists of 18 items based on the original BV Questionnaire constructed. The BVQ-R has recently used in a number of studies in Cyprus after its adaptation into Greek Georgiou [69], Georgiou, Stavrinides [70], Kyriakides et al. [71]. We used the Cypriot version translated in Greek. The scale has two factors and each factor has 9 items. Items from the bullying subscale include statements such as 'Other children are afraid of me'. Items from the victimization subscale include statements such as 'I am afraid of other children'. Students responded to each item on a five-point Likert-type scale, ranging from $1=$ not true at all to $5=$ true at all. Cronbach's alpha reliability for the bullying factor was .87 and for the victimization factor was .85 .

\section{Procedure}

Permission to participate in the study was asked from Ministry of Education, school authorities, as well as from students' parents. Printed questionnaires were given to 247 students of senior high schools. Students filled in the questionnaires at school during a 45-minute teaching hour. Students used numbers instead of names in order to protect their anonymity.

\section{Data Analysis}

For the testing of the hypotheses multiple regressions analysis was applied. Both IOS and boredom were entered as predictors of bullying. A multiple regression technique was also used for the other three hypotheses in which the gender and IOS as predictors of bullying. Then, similar multiple regression, but this time victimization was the dependent variable. In this way, differences between the predictors of bullying and victimization could be identified.

\section{Results}

\section{Tests of Normality}

The normality of the distribution of the bullying and victimization data was tested because there were some outliers. Taking into consideration the Kolmogorov-Smirnov test of normality, the distribution was not normal, D (235) $=.135$, 
$\mathrm{p}<.001$ for bullying, and $\mathrm{D}(235)=.125, \mathrm{p}<.001$ for victimization We further tested the distribution of the data using the Q-Q plot. Considering that our sample was quite large $(\mathrm{N}=247)$, the dots in the Q-Q plot showed a reasonably straight line both for bullying and victimization which suggested a normal distribution. For this reason we proceeded with the analyses.

\section{Boredom, Ios, Gender and Bullying}

Bullying and boredom were expected to be positively associated. In order to verify our first hypothesis, whether boredom is predictor of bullying, a simple linear regression was performed. Preliminary analyses were also conducted to be sure that there was no violation of the assumptions of normality, linearity, multi co linearity and homoscedasticity. The analysis revealed that boredom significantly predicted bullying, $\beta=.10$, $t$ $(227)=3.30, p<.05$. Nonetheless, boredom explained only $4 \%$ of variance of the bullying scores, $R^{2}=.04, F(1,227)=10.89, p<.05$ (Table 3).

The second hypothesis (Hypothesis 2a) referred to that IOS would predict bullying. So, standard multiple regression analysis was conducted to assess the predicting ability of this variable. Preliminary analyses were also conducted to be sure that there is no violation of assumptions of normality, linearity, multi co linearity and homoscedasticity. Some outliers have been identified, however, considering the large sample size ( $N=247)$ and the number of the predictors, they did not influence the regression.

IOS predicted bullying and $5.6 \%$ of bullying was explained by the model $\left(\mathrm{R}^{2}=.056, \mathrm{~F}(2,226)=6.75, \mathrm{p}<.05\right)$ (Table 4). IOS, as stated by the negative beta scores, were negatively associated with bullying but there was no significant prediction here as $\mathrm{p}>.05$. As a result, the hypothesis was not confirmed. Gender made the strongest negatively significant and unique contribution in the prediction of bullying, $(\beta=-.28, \mathrm{t}(217)=$ $-4.31, \mathrm{p}<.001)$. More specifically, boys were involved in more bullying occasions than girls, which means that boys scored higher in bullying (were more often bullies) than girls (Table 4).

\section{IOS, gender, and victimization}

The hypotheses were that IOS and gender would predict victimization (Hypotheses $2 \mathrm{~b}$ and $3 \mathrm{~b}$, respectively). Standard multiple regression analysis was conducted to assess the predicting ability of IOS, and gender on victimization. Taking into account the correlations among the independent variables, it is assumed that multi co linearity is not present in this regression model. Some outliers have been identified, however, considering the sample size $(\mathrm{N}=247)$ and the number of the predictors, they did not influence the regression. Preliminary analyses were conducted to ensure no violation of the assumptions of normality, linearity, multi co linearity and homoscedasticity.

IOS and gender significantly predicted victimization and $8.5 \%$ of the variance of bullying was explained by the model $\left(\mathrm{R}^{2}=.08, \mathrm{~F}(6,222)=3.41 \mathrm{p}<.05\right)$.IOS made a very small negative unique contribution in the prediction of victimization $(\beta=-.15, \mathrm{t}$ $(222)=-2.26, p=.025)$. This means that the higher the relatedness they feel the students for other people around them the less chance they have to be victims in a bullying occasion. As a result, our hypotheses for bullying were partly confirmed as gender did not significantly predict victimization (Table 5).

\section{Discussion}

The goal of this research was to investigate how bullying and victimization are related to boredom and interpersonal closeness of students of senior high school. Research findings revealed that bullying had a positive relationship with boredom, while interpersonal closeness was not related with it. On the other hand, victimization showed a negative relationship with interpersonal closeness. In accordance with other findings Hanish, Guerra [72], Pepler et al. [73], Schäfer et al. [74], Swearer, Espelage [75], in our research boredom was proven to be a predictor of bullying, even though it explained a $4 \%$ of the variance of bullying scores. There is a trend showing that students who bored in the classroom tend to release this negative feeling by being involved in bullying occasions.

This finding highlights the need to investigate the relation between boredom and bullying/victimizationby taking into account individual (e.g. personality traits) and school setting factors (e.g. school climate, teaching style and leadership). The findings of our study showed also that only boredom was a significant predictor of bullying and not interpersonal closeness Vander Zanden et al. [76]. A possible explanation for this unexpected result could be the fact that children may become bullies because of extreme relatedness of themselves with their peers, which means that because they feel so close to people around them, sometimes they want to impose themselves over the others.

Concerning the IOS, the results were in accordance with a really recent research which stated that children who are uncertain in their social relations and in teasing situations are more likely to avoid interaction with other children Reunamo et al. [46]. Indeed, IOS predicted negatively significantly victimization which means that the less related to other people around them are the students they are more likely to be victims of bullying. Our findings were in accordance with past researches Farrington [67], Thorne [68], Eder et al. [66] and Magklara et al. [77], concerning the prediction of bullying by gender as indeed boys bullied more than girls. What is more, similarly with what other researches Farrington [67], Thorne [68], Eder et al. [66], our findings did not show that gender predicted victimization.

\section{Conclusion}

In general the results of our study were really interesting because they introduced a relatively new relationship between boredom and bullying in a school context which was not investigated in the past [78-84]. What is more, according to our findings interpersonal closeness could be a factor which was 
related to victimization, a result which was in accordance with past researches and verified them [85-88]. The following issues need to be addressed when developing anti-bullying programs. Victims should work on developing their social skills and on building close relationships with other students, so as to boost their status in their peer group Andreou et al. [51], which group will then protect them from becoming victimized again.

Concerning the shortcomings of our survey, someone could argue that maybe we should include a wider range of classes and ages of students so as to see the results and findings about bullying and victimization in different ages and whether the phenomena are reducing or increasing as the students get older. A new survey could investigate whether the age or maturity of students can predict bullying and maybe in interaction with the levels of students' empathy towards their peers at school.

\section{Reference}

1. Rigby K (1999) What harm does bullying do? In Children and Crime: Victims and Offenders Conference convened by the Australian Institute of Criminology, Brisbane, Australia, p. 1-12.

2. Rigby K, Johnson B (2006) Expressed readiness of Australian schoolchildren to act as bystanders in support of children who are being bullied. Educational Psychology 26(3): 425-440.

3. Fahlman SA, Mercer-Lynn KB, Flora DB, Eastwood JD (2013) Development and validation of the multidimensional state boredom scale. Assessment 20(1): 68-85.

4. Rupp DE, Vodanovich SJ (1997) The role of boredom proneness in self-reported anger and aggression. Journal of Social Behaviour \& Personality 12: 925-936.

5. Olweus D (1996) The revised Olweus bully/victim questionnaire. University of Bergen, Research Center for Health Promotion.

6. Aron A, Aron EN, Smollan D (1992) Inclusion of other in the self Scale and the structure of interpersonal closeness. Journal of Personality and Social Psychology 63(4): 596-612.

7. Olweus D (2010) Understanding and researching bullying: Some criticalissues. In SR Jimerson, SM Swearer, DL Espelage (Eds.), The handbook of school bullying: An international perspective, New York, USA, pp. 9-33.

8. Volk AA, Dane A V, Marini ZA (2014) What is bullying? A theoretical redefinition. Developmental Review 34: 327-343.

9. Austin S, Joseph S (1996) Assessment of bully/victim problems in 8 to 11 year olds. British Journal of Educational Psychology 66(4): 447-456.

10. Bowers L, Smith PK, Binney V (1994) Perceived family relationships of bullies, victims and bully/victims in middle childhood. Journal of Social and Personal Relationships 11(2): 215-232.

11. Wolke D, Woods S, Bloomfield L, Karstadt L (2000) The association between direct and relational bullying and behavior problems among primary school children. Journal of Child Psychology and Psychiatry 41(8): 989-1002.

12. Bollmer JM, Milich R, Harris M, Maras M (2005) A friend in need: Friendship quality, internalizing/externalizing behavior, and peer victimization. Journal of Interpersonal Violence 20(6): 701-712.

13. Cunningham NJ (2007) Level of bonding to school and perception of the school environment by bullies, victims, and bully victims. Journal of Early Adolescence 27(4): 457-478.
14. Jolliffe D, Farrington DP (2006) The development and validation of the Basic Empathy Scale. Journal of Adolescence 29(4): 589-611.

15. Mouttapa M, Valente T, Gallaher P, Rohrbach LA, Unger JB (2004). Social network predictors of bullying and victimization. Adolescence 39(154): 315-335.

16. Unnever JD (2005) Bullies, aggressive victims, and victims: Are they distinct groups? Aggressive Behaviour 31(2): 153-171.

17. Haynie DL, Nansel T, Eitel P, Davis-Crump A, Saylor et al. (2001) Bullies, victims, and bully/victims: Distinct groups of at-risk youth. Journal of Early Adolescence 21(1): 29-49.

18. Juvonen J, Graham S, Schuster MA (2003) Bullying among young adolescents: The strong, the weak, and the troubled. Pediatrics 112(6): 1231-1237.

19. Marini Z, Dane A, Bosacki S (2006) Direct and indirect bully-victims: differential psychosocial risk factors associated with adolescents involved in bullying and victimization. Aggressive Behaviour 32(6): 551-569.

20. Eastwood JD, Frischen A, Fenske MJ, Smilek D (2012) The unengaged mind: Defining boredom in terms of attention. Perspectives on Psychological Science 7(5): 482-495.

21. Mercer KB, Eastwood JD (2010) Is boredom associated with problem gambling behaviour? It depends on what you mean by "boredom." International Gambling Studies 10(1): 91-104.

22. Joireman J, Anderson J, Strathman A (2003) The aggression paradox: Understanding links among aggression, sensation seeking, and the consideration of future consequences. Journal of Personality and Social Psychology 84(6): 1287-1302.

23. Vodanovich SJ, Kass SJ (1990) A factor analytic study of the boredom proneness scale. Journal of Personality Assessment 55(1-2): 115123.

24. Pekrun R, Hall NC, Goetz T, Perry RP (2014) Boredom and academic achievement: Testing a model of reciprocal causation. Journal of Educational Psychology 106(3): 696-710.

25. Dahlen ER, Martin RC, Regan K, Kuhlman MM (2004) Boredom proneness in anger and aggression: Effects of impulsiveness and sensation seeking. Personality and Individual Differences 37(8): 1615-1627.

26. Larson RW, Richards MH (1991) Boredom in the middle school years: Blaming schools versus blaming students. American Journal of Education 99(4): 418-443.

27. Daschmann EC, Goetz T, Stupnisky RH (2011) Testing the predictors of boredom at school: Development and validation of the precursors to boredom scales. British Journal of Educational Psychology 81(3): 421-440.

28. Robinson WP (1975) Boredom at school. British Journal of Educational Psychology 45(2): 141-152.

29. Wasson AS (1981) Susceptibility to boredom and deviant behavior at school. Psychological Reports 48(3): 901-902.

30. Johnston LD, O Malley PM (1986) Why do the nation's students use drugs and alcohol? Self-reported reasons from nine national surveys. Journal of Drug Issues 16(1): 29-66.

31. Orcutt JD (1984) Contrasting effects of two kinds of boredom on alcohol use. Journal of Drug Issues 14(1): 161-173.

32. Samuels DJ, Samuels M (1974) Low self-concept as a cause of drug abuse. Journal of Drug Education 4(4): 421-438.

33. Abramson EE, Stinson SG (1977) Boredom and eating in obese and non-obese individuals. Addictive Behaviours 2(4): 181-185. 
34. Leon GR, Chamberlain K (1973) Emotional arousal, eating patterns, and body image as differential factors associated with varying success in maintaining a weight loss. Journal of Consulting and Clinical Psychology 40(3): 414-419.

35. Broadbent DE, Gath D (1979) Chronic effects of repetitive and nonrepetitive work. In CJ Mackay, T Cox (Eds.), Response to stress: Occupational aspects. London: International Publishers Corp.

36. Giambra LM, Traynor TD (1978) Depression and daydreaming: An analysis based on self-ratings. Journal of Clinical Psychology 34(1) 14-25.

37. Harris MB (2000) Correlates and characteristics of boredom proneness and boredom. Journal of Applied Social Psychology 30(3): 576-598.

38. Kass SJ, Vodanovich SJ (1990) Boredom proneness: Its relationship to Type A behaviour pattern and sensation seeking. Psychology: A Journal of Human Behaviour 27: 7-16.

39. Greenson RR (1953) On boredom. Journal of the American Psychoanalytic Association 1(1): 7-21.

40. Fahlman SA, Mercer KB, Gaskovski P, Eastwood AE, Eastwood JD (2009) Does a lack of life meaning cause boredom? Results from psychometric, longitudinal, and experimental analyses. Journal of Social and Clinical Psychology 28(3): 307-340.

41. Goldberg YK, Eastwood JD, Laguardia J, Danckert J (2011) Boredom: An emotional experience distinct from apathy, anhedonia, or depression. Journal of Social and Clinical Psychology, 30: 647-666.

42. Passik SD, Inman A, Kirsch K, Theobald D, Dickerson P (2003) Initial validation of a scale to measure purposelessness, understimulation, and boredom in cancer patients: Toward a redefinition of depression in advanced disease. Palliative and Supportive Care 1(1): 41-50.

43. Chapman C, Laird J, Ifill N, Kewal Ramani A (2011) Trends in high schools dropout and completion rates in the United States: 19722009 (NCES 2012-006). National Center for Education Statistics, Institute of Education Sciences, U.S. Department of Education, Washington DC, USA.

44. Fredricks JA (2015) Academic engagement. In J.D. Wright (Ed.), International Eencyclopaedia of the Social and Behavioral Sciences, Oxford: Elsevier, Amsterdam, Netherlands, pp. 31-36.

45. Pellegrini AD, Bartini M, Brooks F (1999) School bullies, victims, and aggressive victims: Factors relating to group affiliation and victimization in early adolescence. Journal of Educational Psychology 91(2): 216-224

46. Reunamo J, Kalliomaa M, Repo L, Salminen E, Lee HC, et al. (2014) Children's strategies in addressing bullying situations in day care and preschool. Early Child Development and Care 185(6): 952-967.

47. Leadbeater B, Sukhawathanakul P, Smith D, Bowen F (2015) Reciprocal associations between interpersonal and values dimensions of school climate and peer victimization in elementary school children. Journal of Clinical Child \& Adolescent Psychology 44(3): 480-493.

48. Andreou E (2000) Bully/victim problems and their association with psychological constructs in 8- to 12-year-old Greek schoolchildren. Aggressive behaviour 26(1): 49-56.

49. Andreou E (2001) Bully/Victim Problems and Their Association with Copying behaviour in Conflictual Peer Interactions among SchoolAge Children. Educational Psychology 21(1): 59-66.

50. Andreou E (2004) Bully/victim problems and their association with Machiavellianism and self-efficacy in Greek primary school children. British Journal of Educational Psychology 74(2): 297-309.
51. Andreou E, Vlachou A, Didaskalou E (2005) The Roles of SelfEfficacy, Peer Interactions and Attitudes in Bully-Victim Incidents. Implications for Intervention Policy Practices. School Psychology International 26(5): 545-562.

52. Kokkinos CM, Panayiotou G (2004) Predicting bullying and victimization among early adolescents: Associations with disruptive behaviour disorders. Aggressive Behaviour 30: 520-533.

53. Psalti A (2012) Bullies, Victims, and Bully-Victims in Greek schools: Research Data and Implications for Practice. Hellenic Journal of Psychology 9: 132-157.

54. Johnson LS (2009) School contexts and student belonging: A mixed methods study of an innovative high school. The School Community Journal 19(1): 99-118.

55. Nipedal C, Nesdale D, Killen M (2010) Social group norms, school norms, and children's aggressive intentions. Aggressive Behavior 36(3): 195-204.

56. Pellegrini AD, Long JD (2002) A longitudinal study of bullying, dominance, and victimization during the transition from primary school through secondary school. British Journal of Developmental Psychology 20(2): 259-280.

57. Farrington DP (1991) Childhood aggression and adult violence: Early precursors and later-life outcomes. The development and treatment of childhood aggression, NJ: Lawrence Erlbaum, Hillsdale, pp. 5-29.

58. Loeber R, Stouthamer-Loeber M (1998) Development of juvenile aggression and violence: Some common misconceptions and controversies. American Psychologist 53(2): 242-259.

59. Nansel TR, Overpeck M, Pilla RS, Ruan WJ, Simons-Morton B, et al. (2001) Bullying behaviours among US youth: Prevalence and association with psychosocial adjustment. Journal of American Medical Association, 285(16): 2094-2100.

60. Pellegrini AD, Bartini M (2000) A longitudinal study of bullying, victimization, and peer affiliation during the transition from primary school to middle school. American Educational Research Journal 37(3): 699-725.

61. Monks CP, Smith PK, Swettenham J (2003) Aggressors, victims, and defenders in preschool: Peer, self-, and teacher reports. MerrillPalmer Quarterly 49(4): 453-469.

62. Monks CP, Smith PK, Swettenham J (2005) Psychological correlates of peer victimisation in preschool: Social cognitive skills, executive function and attachment profiles. Aggressive Behavior 31(6): 571588.

63. Boulton MJ, Smith PK (1994) Bully/victim problems in middle-school children: Stability, self-perceived competence, peer perceptions and peer acceptance. British Journal of Developmental Psychology 12(3): 315-329.

64. Salmivalli C, Lagerspetz K, Björkqvist K, Österman K, Kaukiainen A (1996) Bullying as a group process: Participant roles and their relations to social status within the group. Aggressive Behavior 22(1): 1-15.

65. Stassen, Berger K (2007) Update on Bullying at School: Science Forgotten? Developmental Review 27 (1): 90-126.

66. Eder D, Evans CC, Parker S (1995) School talk: Gender and adolescent culture. NJ: Rutgers University Press, New Brunswick, Canadian Province.

67. Farrington DP (1993) Understanding and preventing bullying. Crime and Justice 17: 381-458.

68. Thorne B (1993) Gender Play: Girls and Boys in School. Rutgers University Press, New Brunswick, New Jersey, USA, pp. 385-387. 
69. Georgiou SN (2008) Bullying and victimization at school: The role of mothers. BritishJournal of Educational Psychology 78(1): 109-125.

70. Georgiou S, Stavrinides P (2008) Bullies, victims and bully victims: Psycho-social profiles and attribution styles. School Psychology International 29(5): 574-589.

71. Kyriakides L, Kaloyirou C, Lindsay G (2006) An analysis of the Revised Olweus Bully/Victim Questionnaire for students using the Rasch measurement model. British Journal of Educational Psychology, 76 (4): 781-801.

72. Hanish DL, Guerra N (2004) Aggressive victims, passive victims, and bullies: Developmental continuity or developmental change? MerrillPalmer Quarterly 50(1): 17-38.

73. Pepler D, Jiang D, Craig W, Connolly J (2008) Developmental trajectories of bullying and associated factors. Child Development 79(2): 325-338.

74. Schäfer M, Korn S, Smith PK, Hunter SC, Mora-Merchán JA, et al. (2004) Lonely in the crowd: Recollections of bullying. British Journal of Developmental Psychology 22(3): 379-394.

75. Swearer SM, Espelage DL (2004) A social-ecological framework of bullying among youth. In DL Espelage, SM Swearer (Eds.), Bullying in American schools: A social-ecological perspective on prevention and intervention, NJ: Erlbaum, Mahwah, New Jersey, USA, p. 1-12.

76. VanderZanden P, Denessen E, Scholte R (2015) The effects of general interpersonal and bullying-specific teacher behaviors on pupils' bullying behaviors at school. School Psychology International, 36(5): 467-481.

77. Magklara K, Skapinakis P, Gkatsa T, Bellos S, Araya R, et al. (2012) Bullying behaviour in schools, socioeconomic position and psychiatric morbidity: a cross-sectional study in late adolescents in Greece. Child and Adolescent Psychiatry and Mental Health 6: 8.

78. Bakirtzis K (2003) Communication and education. Athens: Gutenberg. [In Greek.]
79. Chrysafides K (2000) The importance of communication in school. In Communication in schools, ed. K. Chrysafides, Athens: Typothito, Greek, 11-28.

80. Fahlman SA, Mercer-Lynn, KB, Flora DB, Eastwood J (2013) Development and validation of the multidimensional state boredom scale. Assessment 20(1): 68-85.

81. Giovazolias A (2008) Foreword. In K. Rigby (Ed.), Bullying: Modern views (pp. 11-12). Athens: Topos.

82. Goldberg YK, Eastwood JD, Laguardia J, Danckert J (2011) Boredom: An emotional experience distinct from apathy, anhedonia, or depression. Journal of Social and Clinical Psychology 30: 647-666.

83. Graig MC, Catani M, Deeley Q, Latham R, Daly E, Kanaan R, et al. (2009) Altered connections on the road to psychopathy. Molecular Psychiatry 14(10): 946-953.

84. Leon GR, Chamberlain K (1973) Emotional arousal, eating patterns, and body image as differential factors associated with varying success in maintaining a weight loss. Journal of Consulting and Clinical Psychology 40(3): 414-419.

85. Myers MW, Hodges SD (2006) Perspective taking, self-esteem, and self-other overlap: Seeing the best of me in you. Poster presented at the annual conference of the Society for Personality and Social Psychology, Palm Springs, California, USA.

86. Rekalidou G, Petrogiannis K (2012) Criteria for selection and rejection of social relationships among children in urban and rural kindergartens in Greece. Education 40(2): 173-188.

87. Salmivalli C (2010) Bullying and the peer group: A review. Aggressive Violent Behavior 15(2): 112-120.

88. Mercer KB, Eastwood JD (2010) Is boredom associated with problem gambling behaviour? It depends on what you mean by 'boredom' International Gambling Studies 10(1): 91-104.

\section{Your next submission with Juniper Publishers will reach you the below assets}

- Quality Editorial service

- Swift Peer Review

- Reprints availability

- E-prints Service

- Manuscript Podcast for convenient understanding

- Global attainment for your research

- Manuscript accessibility in different formats

( Pdf, E-pub, Full Text, Audio)

- Unceasing customer service

Track the below URL for one-step submission https://juniperpublishers.com/online-submission.php 